\section{Kjetil Horn}

kjehorn@online.no

DPS Moss

Sykehuset Østfold

Kjetil Horn (f. 1966) er seksjonsleder ved Moss distriktspsykiatriske senter og nestleder i Norsk Forening for Kognitiv Terapi. Ingen oppgitte interessekonflikter.

\section{Litteratur}

1. Gilbert P, Leahy RL. The therapeutic relationship in the cognitive behavioural psychotherapies. New York: Routledge, 2007

2. Beck AT, Rush AJ, Shaw BF et al. Cognitive therapy of depression. New York: Guilford Press, 1979.
3. Barlow DS. Anxiety and its disorders. The nature and treatment of anxiety and panic. New York: Guilford Press, 2002.

4. Kingdon D, Turkington D. Cognitive therapy of schizofrenia. New York: Guilford Press, 2005.

5. Fairburn CG. Cognitive behavior therapy and eating disorders. Oxford: Oxford University Press, 2008.

6. Morley S, Eccleston C. Williams AC. Systematic review and meta-analysis of randomised, controlled trials of cognitive behaviour therapy and behaviour therapy for chronic pain in adults, excluding headache. Pain 1999; 80: 1-13.

7. Kinsella P. Cognitive behavioral therapy for chronic fatigue syndrom. A guide for clinicians. London. Routledge, 2007.

8. Perlis ML, Jungquist C, Smith MT et al. Cognitive behavioral treatment of insomnia. A session-bysession guide. New York: Springer, 2005

9. Gulliksson M, Burell G, Vessby B et al. Randomized controlled trial of cognitive therapy vs standard treatment to prevent recurrent cardiovascular events in patients with coronary heart disease. Arch Intern Med 2011: 17: 134-40.

10. Foley E, Baillie A, Huxter M et al. Mindfulnessbased cognitive therapy for individuals whose lives have been affected by cancer: A randomized controlled trial. J Consult Clin Psychol 2010; 78: 72-9.

11. Safran JD, Segal ZS. Interpersonal process in cognitive therapy. New York: Basic Books, 1990.

12. Nasjonale retningslinjer for diagnostisering og behandling av voksne med depresjon

i primærhelsetjenesten og spesialisthelsetjenesten. Oslo: Helsedirektoratet, 2009

13. Psykisk helsevern for voksne, prioriteringsveileder. Veiledertabell november 2008. Oslo: Helsedirektoratet, 2008

Mottatt 21.6. 2011, første revisjon innsendt 18.8. 2011, godkjent 15.9. 2011. Medisinsk redaktør Anne Kveim Lie.

\title{
Overflødig undersøkelse?
}

Som helsestasjonslege i over 30 år har jeg samvittighetsfullt utført Moros refleks ved seksukerskontrollen. Jeg brukte å utløse den ved å la barnets hode $\mathrm{i}$ hånden min plutselig falle noen centimeter. Barnet slår da ut med armene. I løpet av disse årene har jeg ikke oppdaget ett eneste avvik av betydning.

Dette har satt meg på tanken om at denne undersøkelsen kanskje er overflødig? Refleksen synes å være et uttrykk for at barnet blir skremt. Den har kanskje en beskyttende effekt, slik at nyfødte unger blir behandlet forsiktig.

Moderne forskning på tilknytning tyder på at det første halvåret av barnets liv har stor betydning for tilknytningen til andre mennesker. I hvilken alder spesielle opplevelser begynner å få betydning for den videre utvikling er omdiskutert. Enkelte mødre får inntrykk av at legen er ufølsom når han fremkaller en fryktreaksjeon hos barnet. Og hvis sjekking av Moros refleks strengt tatt ikke er medisinsk nødvendig, er det kanskje like godt å la det være?

\section{Arne Tveit}

arne.tveit@broadpark.no

Bergen

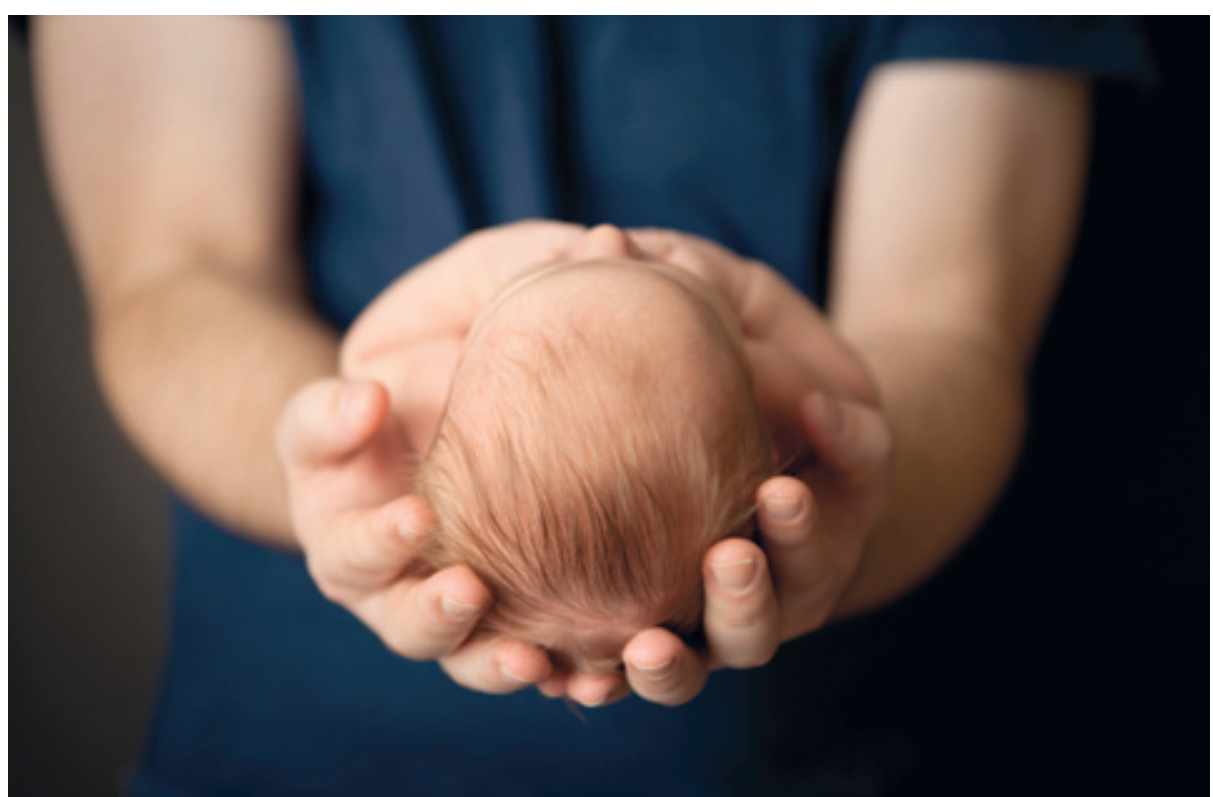

Illustrasjonsfoto Istockphoto

Arne Tveit (f. 1928) er pensjonert barnelege. Ingen oppgitte interessekonflikter.
Mottatt 2.8. 2011 og godkjent 1.9. 2011. Medisinsk redaktør Anne Kveim Lie. 